\title{
EVALUASI SISTEM INFORMASI SUMBER DAYA MANUSIA PADA BIDANG USAHA JASA
}

\author{
Noerlina \\ Jurusan Komputerisasi Akuntansi, Fakultas Ilmu Komputer, Universitas Bina Nusantara, \\ Jln. K.H. Syahdan No.9, Palmerah, Jakarta Barat 11480 \\ noerlina@binus.edu
}

\begin{abstract}
Human Resource Information System has become a reference to get assurances from the availability of appropriate manpower to occupy a position and the right job and right time for organizations to realize the goals and objectives of the company. Therefore, the company will be in desperate need of a performance of high quality human resources. The evaluation of Human Resource Information System is needed to improve the performance of the required human resources activities, including internal within the company such as recruiting, selecting, training for new employees.
\end{abstract}

Keywords: evaluation, Information System, Human Resource

\begin{abstract}
ABSTRAK
Sistem Informasi Sumber Daya Manusia telah menjadi suatu acuan untuk mendapatkan jaminan dari tersedianya tenaga kerja yang tepat untuk menduduki suatu jabatan dan pekerjaan yang tepat dan waktu yang tepat bagi organisasi untuk mewujudkan tujuan dan sasaran perusahaan. Oleh karena itu, perusahaan akan sangat membutuhkan sebuah kinerja dari Sumber Daya Manusia yang berkualitas tinggi. Evaluasi terhadap Sistem Informasi Sumber Daya Manusia diperlukan untuk meningkatkan kinerja dari Sumber Daya Manusia yang dibutuhkan, meliputi kegiatan didalam internal perusahaan seperti perekrutan, penyeleksian, pelatihan untuk karyawan baru.
\end{abstract}

Kata kunci: evaluasi, Sistem Informasi, Sumber Daya Manusia

\section{PENDAHULUAN}

Dalam era globalisasi saat ini, banyak sekali perusahaan yang tidak mampu untuk dapat bersaing di dunia bisnis dengan tingkat persaingan yang semakin kompetitif. Banyak faktor yang menyebabkan perusahaan tersebut tidak mampu bersaing dengan perusahaan lain. Salah satu faktor yang menyebabkan perusahaan tersebut tidak mampu bersaing dengan perusahaan lain adalah karena sistem yang digunakan tidak mampu untuk dapat mendukung seluruh kegiatan perusahaan tersebut. Oleh karena itu, dibutuhkan suatu Sistem Informasi yang dapat mendukung tersedianya informasi yang dibutuhkan oleh perusahaan tersebut. Tersedianya informasi yang spesifik, cepat, tepat, akurat, dan dapat diandalkan merupakan hal yang sangat penting bagi suatu perusahaan karena dapat membantu manajemen dalam pengambilan keputusan.

Sistem Informasi Sumber Daya Manusia telah menjadi suatu acuan untuk mendapatkan jaminan dari tersedianya tenaga kerja yang tepat untuk menduduki suatu jabatan dan pekerjaan yang tepat dan waktu yang tepat bagi organisasi untuk mewujudkan tujuan dan sasaran perusahaan. Di dalam dunia bisnis yang semakin berkembang ini, perusahaan akan sangat membutuhkan sebuah kinerja dari Sumber Daya Manusia yang berkualitas tinggi. Untuk itu, perusahaan harus melakukan suatu pelatihan yang dapat membantu meningkatkan kualitas dari Sumber Daya Manusianya. Dengan begitu, Sistem Informasi dianggap penting untuk mendukung kegiatan tersebut.

Evaluasi diperlukan untuk memastikan Sistem Informasi yang ada sudah sesuai dengan standar dan ketentuan perusahaan. Evaluasi dapat meliputi sebagai berikut. Pertama, evaluasi terhadap Sistem Informasi Sumber Daya Manusia yang berjalan, yang meliputi kegiatan di dalam internal perusahaan seperti perekrutan, penyeleksian, dan pelatihan untuk karyawan baru. Kedua, evaluasi terhadap pengendalian prosedur dan pelaksanaan sistem yang meliputi hal-hal seperti (1) evaluasi terhadap pengendalian aplikasi (application control), yaitu boundary control (pengendalian batasan), input control (pengendalian masukan), dan output control (pengendalian keluaran); (2) evaluasi terhadap pengendalian umum (general control), yaitu security management control (pengendalian manajemen keamanan) dan operation management control (pengendalian manajemen operasi).

Permasalahan yang dihadapi terkait dengan sistem Sumber Daya Manusia adalah pengendalian umum dan aplikasi sering tidak terukur, bahkan tidak terimplementasi dengan baik sesuai dengan standar-standar yang berlaku sehingga dapat merugikan perusahaan, baik dari segi finansial maupun non-finansial.

Tujuan penelitian adalah meningkatkan objektifitas keamanan asset perusahaan terutama Sumber Daya Manusia perusahaan; meningkatkan objektifitas integritas data dalam sistem Sumber Daya Manusia; dan meningkatkan objektifitas efektifitas dan efisiensi sistem Sumber Daya Manusia.

\section{Metode Penelitian}

Evaluasi Sistem Informasi dilakukan dalam beberapa tahap untuk menjamin dihasilkannya temuan yang sesuai dengan standar dan ketentuan yang berlaku. Standar yang digunakan berupa pendekatan audit Sistem Informasi dan teknologi informasi yang normal berlaku di perusahaan. Berikut merupakan langkah-langkah yang diambil dalam 
melakukan evaluasi Sistem Informasi, yaitu audit planning, control evaluation, recommendation, dan audit report.

\section{Tinjauan Pustaka}

Menurut Weber (1990: 10), audit Sistem Informasi secara garis besar dapat diartikan sebagai proses pengumpulan dan pengevaluasian bukti-bukti untuk menentukan apakah sebuah sistem komputer dapat melindungi asset perusahaan, memelihara integritas data dan memungkinkan tujuan organisasi untuk dicapai secara efektif dengan menggunakan sumber daya yang efisien.

Tujuan audit Sistem Informasi menurut Weber (1999: 11-13) dapat disimpulkan bahwa secara garis besar terbagi menjadi 4 tahap, yaitu meningkatkan objektifitas keamanan asset perusahan, meningkatkan objektifitas integritas data, meningkatkan objektifitas efektifitas sistem, dan meningkatkan objektifitas efisiensi sistem.

Menurut Romney dan Steinbart (2003: 322-324), langkah-langkah dalam melakukan audit Sistem Informasi adalah merencanakan audit, mengumpulkan bukti audit mengevaluasi bukti audit, dan mengkomunikasikan hasil audit. Sedangkan menurut Nawawi (2001: 40), terdapat 3 pengertian yang masing-masing berisikan sebagai berikut. Pertama, Sumber Daya Manusia adalah manusia yang bekerja dilingkungan suatu organisasi (disebut juga personil, tenaga kerja, pekerja atau karyawan). Kedua, Sumber Daya Manusia adalah potensi yang merupakan aset dan berfungsi sebagai model (non material/non finansial) di dalam organisasi bisnis, yang dapat diwujudkan menjadi potensi nyata secara fisik dan non fisik dalam mewujudkan eksistensi organisasi. Ketiga, Sumber Daya Manusia adalah potensi manusiawi sebagai penggerak organisasi dalam mewujudkan eksistensinya. Sementara itu, menurut Mcleod (2001: 525), Sistem Informasi Sumber Daya Manusia adalah suatu sistem untuk mengumpulkan dan memelihara data yang menjelaskan Sumber Daya Manusia, mengubah data tersebut menjadi informasi, dan melaporkan informasi tersebut kepada pemakai.

Tahapan Sumber Daya Manusia adalah sebagai berikut. Pertama, perekrutan karyawan. Menurut Mcleod (2001: 443), perekrutan di dalam Sistem Informasi Sumber Daya Manusia adalah mendapatkan karyawan baru untuk organisasi, dengan cara melakukan periklanan di surat kabar, dan menyediakan permintaan-permintaan posisi kepada pemerintah maupun agen swasta. Kedua, penyeleksian karyawan. Menurut Hasibuan (1997: 52), seleksi adalah suatu kgiatan pemilihan dan penentuan pelamar, yang diterima atau ditolak untuk menjadi karyawan perusahaan itu. Ketiga, pelatihan dan pengembangan karyawan. Menurut Hariandja (2005: 168), pelatihan dapat didefinisikan sebagai usaha yang terencana dari organisasi untuk meningkatkan pengetahuan, ketrampilan, dan kemampuan karyawan. Keempat, penilaian kinerja karyawan. Menurut Sulistiyani dan Rosidah (2003: 223), penilaian kinerja merupakan cara pengukuran kontribusi-kontribusi dari individu yang dilakukan terhadap organisasi. Kelima, mutasi dan promosi. Menurut Hasibuan (1997: 114), mutasi adalah suatu perubahan posisi/jabatan/ tempat/pekerjaan yang dilakukan, baik secara horisontal maupun vertikal (promosi/demosi) di dalam satu organisasi. Keenam, pemutusan hubungan kerja. Pemutusan Hubungan Kerja (PHK) adalah pengakhiran hubungan kerja karena suatu hal tertentu yang mengakibatkan berakhirnya hak dan kewajiban (prestasi dan kontra prestasi) antara pekerja/buruh dengan pengusaha.

Jenis pengendalian internal dibagi menjadi dua, yaitu pengendalian umum dan pengendalian aplikasi. Pengendalian umum ialah sistem pengendalian internal komputer yang berlaku umum meliputi seluruh kegiatan komputerisasi sebuah organisasi secara menyeluruh. Artinya adalah ketentuanketentuan yang berlaku dalam pengendalian tersebut, berlaku untuk seluruh kegiatan komputerisasi di perusahaan (Weber, 1999: 67).
Sedangkan pengendalian aplikasi dilakukan bahwa sistem aplikasi itu sendiri dapat menjaga aset, memelihara integritas data serta mencapai sasaran yang efektif dan efisien. Pengendalian aplikasi dapat berupa pengendalian batasan (boundary control). Tujuan dari boundary control adalah untuk menetapkan identitas dan otentikasi user terhadap sistem computer; menetapkan identitas dan kebenaran sumber informasi yang digunakan user; dan membatasi kegiatan user dalam mendapat sumber informasi berdasarkan kewenangan (Weber, 1999: 365).

Jenis-jenis pengendalian dalam subsistem boundary yang dibahas adalah sebagai berikut. Pertama, cryptographic control (pengendalian kriptografi). Pengendalian kriptografi dirancang untuk menjaga kerahasiaan data dan untuk mencegah penyalahgunaan pengubahan data oleh orang yang tidak berwenang; yaitu dengan cara mengacak data sehingga tidak memiliki arti bagi orang yang tidak memiliki sistem untuk mengubah kembali data tersebut. Kedua, access control (pengendalian akses). Pengendalian akses berfungsi untuk membatasi penggunaan sumber daya sistem komputer, membatasi, dan memastikan user untuk mendapatkan sumber daya yang mereka butuhkan.

\section{PEMBAHASAN}

Dari pelaksanaan evaluasi terhadap Sistem Informasi Sumber Daya Manusia yang dilakukan selama x bulan, didapatkan temuan-temuan permasalahan pada pengendalian umum, yang meliputi pengendalian manajemen operasional dan pengendalian manajemen keamanan serta pengendalian aplikasi, yang meliputi pengendalian boundary, input, dan output.

Temuan pada Pengendalian Operasional adalah sebagai berikut. Temuan pertama, pelatihan terhadap karyawan tidak dilakukan secara berkala oleh perusahaan dan disesuaikan jika terdapat kebutuhan pada setiap bagian. Resikonya adalah karyawan tidak mendapatkan pengembangan keterampilan kinerja dan tidak ada peningkatan kemampuan melakukan pekerjaan untuk mendukung kinerjanya di dalam perusahaan. Sementara itu, rekomendasi yang diberikan adalah sebaiknya perusahaan memberikan pelatihan secara berkala untuk setiap karyawan yang ada baik karyawan lama maupun karyawan baru dengan tujuan untuk dapat mengembangkan pengetahuan dan keterampilan dari setiap karyawan. Dengan demikian, risk measurement nya adalah medium. Temuan kedua, sistem absensi terhadap karyawan tidak diberlakukan login absensi secara bebas. Resikonya adalah karyawan tidak mendapatkan efektivitas dan efisien, pada saat jika terdapat keterlambatan hadir maupun resiko lainnya. Sementara itu, rekomendasi yang diberikan adalah sebaiknya perusahaan membuat sistem absensi secara online dengan tujuan mendapatkan efisiensi dan efektifitas setiap karyawan. Dengan demikian, risk measurement nya adalah medium. Temuan ketiga, setiap komputer karyawan tidak semuanya menggunakan jaringan internet, tetapi hanya bagian-bagian tertentu saja yang terhubung jaringan internet. Resikonya adalah kemampuan karyawan tidak berkembang dan pemenuhan informasi yang di inginkan perusahaan tidak sepenuhnya di dapat, karena hanya bagian tertentu saja yang dapat mengakses internet. Sementara itu, rekomendasi yang diberikan adalah sebaiknya dilakukan riset atau peninjauan kembali tentang fungsi penggunaan internet untuk setiap karyawan maupun staf yang membutuhkan informasi untuk dirinya maupun untuk kebutuhan informasi dan perkembangan perusahaan. Dengan demikian, risk measurement nya adalah low. Temuan keempat, perusahaan belum melakukan mutasi secara berkala. Resikonya adalah karyawan akan mengalami kejenuhan karena tidak adanya perubahan dalam lingkungan kerjanya serta motivasi dalam bekerja akan berkurang. Sementara itu, rekomendasi yang diberikan adalah sebaiknya perusahaan melakukan mutasi secara berkala yang sesuai dengan kemampuan dan ketrampilan para karyawannya.. Dengan demikian, risk measurement nya adalah medium. 
Temuan pada Pengendalian Keamanan adalah sebagai berikut. Temuan pertama, karyawan tidak melakukan scan antivirus secara berkala pada setiap komputer yang ada pada perusahaan. Resikonya adalah seharusnya karyawan melakukan scan antivirus pada setiap komputer yang ada di perusahaan, hal ini bertujuan untuk mencegah adanya serangan virus yang masuk ke dalam sistem komputer perusahaan yang dapat merusak data, merusak software, mengganggu jalannya sistem dan dapat juga menjebol keamanan informasi perusahaan. Scan antivirus sebaiknya dilakukan oleh bagian IT setiap 1 minggu sekali untuk mengurangi resiko tersebut. Sementara itu, rekomendasi yang diberikan adalah sebaiknya perusahaan memberikan pelatihan secara berkala untuk setiap karyawan yang ada baik karyawan lama maupun karyawan baru dengan tujuan untuk dapat mengembangkan pengetahuan dan keterampilan dari setiap karyawan. Dengan demikian, risk measurement nya adalah medium. Temuan kedua, perusahaan tidak memiliki prosedur tertulis mengenai hacking, selama ini perusahaan belum memperhatikan tentang pencegahan hacking. Resikonya adalah keamanan dan kerahasiaan data tidak bisa terjamin yang bisa berdampak pada kerugian perusahaan. Sementara itu, rekomendasi yang diberikan adalah sebaiknya perusahaan memiliki prosedur tertulis tentang pencegahan hacking. Untuk menghindari kemungkinan data perusahaan yang digunakan oleh orang yang tidak bertanggung jawab untuk kepentingan pribadi. Dengan demikian, risk measurement nya adalah high.

Temuan pada Pengendalian Boundary adalah sebagai berikut. Temuannya adalah sistem komputer tidak dapat melakukan log off secara otomatis ketika user meninggalkan komputer dalam jangka waktu tertentu. Resikonya adalah orang yang tidak berwenang bisa mengakses sistem aplikasi yang terdapat dalam komputer perusahaan sehingga data bisa saja dirubah atau dicuri oleh orang yang tidak berwenang. Sementara itu, rekomendasi yang diberikan adalah sebaiknya perusahaan menggunakan sistem log off secara otomatis pada setiap komputer yang ada pada perusahaan. Dengan demikian, risk measurement nya adalah medium.

Temuan pada Pengendalian Input adalah sebagai berikut. Temuannya adalah kesalahan yang sudah di-input oleh user tidak dapat langsung di-delete tanpa adanya konfirmasi dari bagian IT. Resikonya adalah sering terjadinya keterlambatan dalam pembuatan laporan, yang dapat mengganggu kinerja perusahaan. Sementara itu, rekomendasi yang diberikan adalah sebaiknya ada pengecekan sistem secara otomatis apabila terjadi kesalahan dalam meng-input data sehingga adanya pengendalian terhadap data yang di-input. Dengan demikian, risk measurement nya adalah medium.

Temuan pada Pengendalian Output adalah sebagai berikut. Temuan pertama, laporan yang dihasilkan terkadang tidak tepat waktu dan sering mengalami keterlambatan. Resikonya adalah proses kinerja di dalam perusahaan menjadi terhambat. Sementara itu, rekomendasi yang diberikan adalah laporan yang didistribusikan harus tepat waktu agar pihak yang membutuhkan laporan tersebut dapat langsung mendapatkan laporan yang diinginkannya karena laporan merupakan salah satu jenis informasi yang sangat diperlukan terutama dalam hal pengambilan keputusan. Dengan demikian, risk measurement nya adalah medium. Temuan kedua, laporan yang dihasilkan tidak dicantumkan tanggal, bulan tahun, dan waktu pencetakan. Resikonya adalah laporan tidak dapat diidentifikasi kapan waktu penggunaanya. Sementara itu, rekomendasi yang diberikan adalah sebaiknya setiap laporan harus dicantumkan tanggal, bulan, tahun, dan waktu pencetakan agar laporan yang digunakan selalu up to date. Dengan demikian, risk measurement nya adalah high.

\section{PENUTUP}

Simpulan yang didapat dari penelitian ini adalah perusahaan sebaiknya melakukan evaluasi terhadap keseluruhan Sistem Informasi, yang dijalankan sesuai dengan standar yang digunakan sebagai panduan evaluasi; perusahaan melakukan tindakan preventif untuk mencegah beberapa ancaman atau risiko yang akan terjadi di masa mendatang dengan membuat suatu prosedur tertulis; perusahaan melakukan briefing terhadap semua karyawan mengenai prosedur tertulis untuk menghindari kerancuan, agar karyawan dapat melaksanakan prosedur tersebut dengan baik; dan perusahaan membentuk suatu manajemen risiko untuk mengidentifikasi risiko-risiko yang mungkin terjadi dari proses bisnis yang dijalankan.

\section{DAFTAR PUSTAKA}

Gondodiyoto, S., dan Hendarti, H. (2006). Audit sistem informasi, Jakarta: Mitra Wacana Media.

Hall, James A. (2001). Sistem informasi akuntansi, buku satu, edisi pertama. Diterjemahkan oleh Amir Abadi Jusuf dan Rudi M. Tambunan, Jakarta: Salemba Empat.

Hariandja, Marihot. T. E. (2005). Manajemen sumber daya manusia: Pengadaan, pengembangan, pengkompensasian, dan peningkatan produktivitas pegawai, Jakarta: PT Gramedia Widia Sarana Indonesia.

Hasibuan, Malayu. (2003). Manajemen sumber daya manusia, edisi revisi, Yogyakarta: Kanisius.

Husein, Umar. (2005). Evaluasi kinerja perusahaan, Jakarta: PT Gramedia Pustaka Utama.

Mathis, Robert L., dan John H. Jackson. (2001). Manajemen sumber daya manusia, buku satu. Diterjemahkan oleh Jimmy Sadeli dan Bayu P. H., Jakarta: Salemba Empat.

Mcleod, Jr, R., and Schell, G. (2001). Management information system, $8^{\text {th }}$ ed., New Jersey: Prenhall.

Mulyadi. (2002). Auditing, buku kedua, edisi keenam, cetakan kedua, Jakarta: Salemba Empat.

Nawawi, Hadari. (2001). Manajemen sumber daya manusia untuk bisnis yang kompetitif, cetakan keempat, Yogyakarta: Gadjah Mada University Press.

O'Brien, James A. (2005). Pengantar sistem informasi perspektif bisnis dan manajerial, edisi keduabelas. Diterjemahkan oleh Dewi, F dan Deny, A.K., Jakarta: Salemba Empat.

Romney, Marshall B., and Paul John Steinbart. (2003). Accounting information system, $9^{\text {th }}$ ed., New Jersey: Pearson Education International.

Sulistiyani, Rosidah. (2003). Efektivitas sumber daya manusia, edisi kedua, Jakarta: BPK Gunung Mulia.

Valacich, Joseph.S., George, and Hoffer. (2001). Essential of systems analysis and design, New Jersey: Prentice-Hall, Inc.

Weber, R. (1999). Information system control and audit, New Jersey: Prentice-hall, Inc. 